\title{
COLLEGE GLUTINOSA LUCERNE
}

\author{
J. G. H. White, G. Meijer \\ Plant Science Department, Lincoln College
}

\section{J. A. Douglas}

Ministry of Agriculture and Fisheries, Ruakura

\section{Abstract}

College Glutinosa was selected from Glutinosa lucerne for earlier spring growth, greater vigour, improved rhizomatous creep and better seed production. It was released as a certified cultivar in 1969. Trials show that it is an alternative to Wairau for grazing, particularly on shallow droughty soils, and should be sown without companion grasses and grazed rotationally. This cultivar also has potential for oversowing on steep, dry, hill country in the South Island because of its persistence and creeping habit.

\section{INTRODUCTION}

Guutinosa lucerne (Medicago glutinosa $\mathrm{MB}$ ) is native to the sub-alpine zone of the Caucasus mountains in southern Russia. It was introduced into New Zealand from Canada in 1937 by Crop Research Divisioa, DSIR, who supplied seed to Lincoln College for the establishment of 0.4 ha of spaced plants (Calder and Iversen, 1957). The unimproved Glutinosa, classified by Iversen and Meijer (1967) as a Medicago falcata hybrid, showed considerable variability. The growth form ranged from prostrate to erect, while only a small proportion of plants showed rhizomataus creep. Most flowers were purple or blue, but a small proportion were white or cream in colour (Calder and Iversen, 1957).

Seed from the spaced plants was used to establish 3 ha at Ashley Dene in 1945, and nine years later Professor J. W. Calder collected seed from surviving plants to commence an improvement programme based on the assumption that a creeping lucerne was better adapted to grazing than the common Medicago sativa. He established spaced plants at Lincoln College, selecting for earlier spring growth, greater vigour, improved rhizomatous creep and better seed production. Diallel crosses involving 72 
selected parents in groups of 12 were set up and the progeny tested. A final selection of six parents was made in 1963 by C. E. Iversen and subsequently compared with the standard cultivar, N.Z. Wairau lucerne under grazing in various parts of New Zealand. From the results of these trials the new selection was released in 1969 as a certified cultivar, College Glutinosa. Since then trials have continued and further comparisons made, the results of which are reported here.

\section{PERFORMANCE OF ADVANCED SELECTIONS OF GLUTINOSA}

\section{LUCERNE}

Under haying, the unimproved Glutinosa is significantly lower yielding than standard hay varieties such as Wairau (Iversen, 1961) the main deficiencies in production occurring in late autumn and early spring. However, Iversen (1967) found that on a Wakanui soil under rotatioaal grazing unimproved Glutinosa was significantly higher yielding than Wairau over a 5-year period.

In a five-year grazing trial on shallow soils at Ashley Dene, an early selection of Glutinosa was compared with Wairau, Provence and Italian cultivars by Iversen $(1965,1967)$ under rotational grazing or set-stocking. The best varieties, Glutinosa and Wairau, were not significantly different in dry matter production, but the percentage plant survival of Glutinosa was superior to Wairau after 5 years, particularly under set-stocking.

The performance of unimproved Glutinosa in grass/legume mixtures at Ashley Dene convinced Calder and Iversen that this cultivar was more compatible with grasses than Wairau (Iversen, 1967). This conclusion was critically examined on a Wakanui soil by Vartha (1973) who compared an advanced selection of Glutinosa with Wairau lucerne, each overdrilled with either Grasslands Ariki ryegrass or Grasslands Apanui cocksfoot. Shortduration rotational grazing with sheep was carried out at either pre-flowering or early flowering stages of growth. Production from the two cultivars was similar except in the third year when legume yield from Wairau was higher than from Glutinosa. There was no conclusive evidence that Glutinosa was more compatible with grasses than Wairau under either grazing system; when plots, were grazed at early flowering both grasses showed poor persistence. Thds agrees with the experience of Iversen (1967) with unimproved Glutinosa sown with grass. 


\section{CERTIFIED COLLEGE GLUTINOSA}

Trials under grazing with the final selection, College Glutinoaa, were carried out in Canterbury (Ashley Dene, Mesopotamia and Oxford), Marlborough (Seddoa), Manawatu (Flock House), and Hawke's Bay (Takapau). The following results were obtained.

\section{A Shley Dene}

A field trial with four replicates was established at Ashley Dene on an Eyre stony silt loam in October 1964 to compare College Glutinosa, unimproved Glutinasa and Wairau lucernes, with and without associated species. Lucerne was sown at $11.2 \mathrm{~kg} /$ ha alone or at $5.6 \mathrm{~kg} / \mathrm{ha}$ with a mixture of $1.1 \mathrm{~kg}$ of each of Apanui cocksfoot, Grasslands Huia white clover and Mt Barker subterranean clover. Once established, plots were sampled when the lucerne was in the late bud/early flowering stage of growth followed by quick grazing with a large mob of sheep. Table 1 shows the mean yields for four years following establishment.

TABLE 1: MEAN ANNUAL DRY MATTER YIELDS AT ASHLEY DENE, 1965-6 TO 1968-9 (kg/ha)

\begin{tabular}{|c|c|c|c|}
\hline & Lucerne & $\begin{array}{l}\text { Cocksfoot } \\
\text { and Other }\end{array}$ & Total \\
\hline College Glutinosa & 5820 & - & 5820 a" \\
\hline Wairau & 5450 & - & 5450 b \\
\hline Unimproved Glutinosa & 5220 & & $5220 \mathrm{c}$ \\
\hline College Glutinosa mixture & 2650 & 3000 & 5650 ab \\
\hline Wairau mixture & 2840 & 2730 & $5570 \mathrm{~b}$ \\
\hline Unimproved Glutinosa mixture & 2430 & 2890 & $5320 \mathrm{bc}$ \\
\hline
\end{tabular}

* Means without a common letter differ significantly at the 5\% level.

College Glutinosa was significantly higher yielding than either Wairau or unimproved Glutinosa when sown alone, although no significant differences occurred in the presence of cocksfoot. There was no significant difference between yields of all three cultivars in the spring cut but unimproved Glutinosa was consistently lower yielding in the second and third cuts. As expected, yield of legume was markedly reduced by the addition of cocksfoot, although total yield was not affected. The proportion of cocksfoot declined from $66 \%$ in the first year of the trial to $27 \%$ in the final year; but there was little to indicate that Glutinoaa was more compatible with grasses than Wairau. 
The trial was rotationally grazed for a further four years, when plants were examined for rhizomatous creep. No evidence of creep was observed in either College Glutinosa or the unimproved strain.

\section{MESOPOTAMIA}

A field trial with six replicates was established on a Mesopotamia soil in the Upper Rangitata Valley on October 1, 1965, to compare pure Wairau lucerne with College Glutinosa sown alone (lucerne, $15.7 \mathrm{~kg} / \mathrm{ha})$ or with Apanui cocksfoot $(2.2 \mathrm{~kg} /$ ha) or Butt's strain of prairie grass $(22.4 \mathrm{~kg} / \mathrm{ha})$. Grazing management was similar to that used at Ashley Dene. Table 2 shows results from two seasons, 1967-8 and 1968-9.

TABLE 2: MEAN ANNUAL DRY MATTER YIELDS MESOPOTAMIA $(\mathrm{kg} / \mathrm{ha})$

\begin{tabular}{lrcr}
\hline & Lucerne & Grass & Total \\
\hline 1967-S: & & & \\
College Glutinosa & 12850 & - & $12850 \mathrm{~b}$ \\
College Glutinosa + cocksfoot & 7440 & 4530 & $11970 \mathrm{~b}$ \\
College Glutinosa + prairie grass & 11790 & 1030 & $12820 \mathrm{~b}$ \\
Wairau & 15780 & - & $15780 \mathrm{a}$ \\
1968-9: & 10530 & & $10530 \mathrm{a}$ \\
College Glutinosa & 5680 & 3850 & $9530 \mathrm{~b}$ \\
College Glutinosa + cocksfoot & 8630 & 1270 & $9900 \mathrm{~b}$ \\
College Glutinosa + prairie grass & 10780 & - & $10780 \mathrm{a}$ \\
Wairau & & &
\end{tabular}

In the first season both the spring cut and total yield of Wairau lucerne were significantly higher than College Glutinosa, but in the second season yields were similar. The presence of grasses depressed both legume and total yield, particularly in 1968-9, but prairie grass had much less effect than cocksfoot.

\section{National TRials}

College Glutinosa was included in five lucerne grazing trials established by the Department of Agriculture in 1967 and 1968. Table 3 summarizes the yields at four of these sites. At Oxford and Takapau A sites the yields are the mean of 5.6 and $11.2 \mathrm{~kg} / \mathrm{ha}$ sowing rates; at the other two sites the rate of sowing was 13.4 $\mathrm{kg} / \mathrm{ha}$. The sampling and grazing techniques were similar to those used at Ashley Dene. 
TABLE 3: MEAN ANNUAL DRY MATTER YIELDS OF COLLEGE GLUTINOSA AND WAIRAU LUCERNES, NATIONAL TRIALS $(\mathrm{kg} / \mathrm{ha})$

\begin{tabular}{|c|c|c|c|c|}
\hline Site & Soil Type & $\begin{array}{c}\text { Period of } \\
\text { Production } \\
\text { Measurement }\end{array}$ & Wairau & $\begin{array}{c}\text { College } \\
\text { Glutinosa }\end{array}$ \\
\hline $\begin{array}{l}\text { Oxford, } \\
\text { Canterbury }\end{array}$ & $\begin{array}{l}\text { Hororata stony } \\
\text { silt loam }\end{array}$ & $1968-9$ to $1971-2$ & $6290 \mathrm{~b}$ & $6700 a$ \\
\hline $\begin{array}{c}\text { Flock House } \\
\text { Manawatu }\end{array}$ & Himatangi sand & $1968-9$ to $1971-2$ & $17800 \mathrm{a}$ & $17600 \mathrm{a}$ \\
\hline $\begin{array}{l}\text { Takapau A, } \\
\text { Hawke's Bay }\end{array}$ & $\begin{array}{l}\text { Takapau silt } \\
\text { loam }\end{array}$ & $1967-8$ to $1971-2$ & $11830 \mathrm{a}$ & $11530 \mathrm{a}$ \\
\hline $\begin{array}{l}\text { Takapau B, } \\
\text { Hawke's Bay }\end{array}$ & $\begin{array}{l}\text { Takapau silt } \\
\text { loam }\end{array}$ & $1968-9$ to $1971-2$ & $12090 \mathrm{a}$ & $10980 \mathrm{~b}$ \\
\hline
\end{tabular}

At Oxford, College Glutinosa significandy out-yielded Wairau in three out of four years, but no differences were measured at Flock House or the Takapau A site, while Wairau was superior to College Glutinosa in the Takapau B trial. At Seddon, Marlborough, only occasional cuts were taken over the period 196872 but yields from the two cultivars were similar. A major difference in seasonal yield occurred at North Island sites in. the autumn when Wairau significantly outproduced College Glutinosa.

\section{DISCUSSION}

College Glutinosa is a shorter, more prostrate leafier cultivar than $M$. sativa lucernes such as Wairau. Flower colour is mainly purple or blue, with some variegation. Our grazing trials have shown that College Glutinolsa is likely to outyield Wairau on shallow stony soils in low rainfall districts, although there is little difference in production under higher rainfall, North Island conditions, where autumn production from College Glutinosa is less than Wairau. At Ashley Dene, spring growth commences 7 to 10 days latter than in Wairau, but this difference disappears by the time the first yield cut is taken.

College Glutinolsa has been compared with nine other lucerne cultivars for seven years under both haying and rotational grazing on a Lismore soil with and without irrigation at Winchmore Irrigation Research Station (Jansoa and Knight, 1972). College Glutinolsa and Wairau were the highest yielding lucernes undea either haying or grazing, and liveweight gains of sheep on the two cultivars were identical. Janson and Knight conclude that, 
because of its erect habit, Wairau is more suitable for cutting, but College Glutinosa. may be better where a stand is used primarily for grazing because of its more prostrate nature, tendency to creep, and possible better persistence.

The results of Iversen $(1965,1967)$ indicate that, for highest yields, College Glutinosa should: be rotationally grazed. This management system produced $30 \%$ more total dry matter and 53\% more lucerne than continuous set-stocking even though plant survival of Glutinosa was relatively better than other cultivars under this severe treatment.

In a study of crown development of College Glutinosa and Moapa lucernes, Musgrave (1972) found that College: Glutinosa developed significantly more stubble and crown shoots when de. foliated at $5 \mathrm{~cm}$ height. This was due to shorter internodes which gave a greater number of sites for shoot regeneration close to ground level. This could well be the reason for the better plant survival of Glutinosa as compared with Wairau which Iversen (1965) measured at Ashley Dene.

Calder and Iversen (1957) advocated the use of Glutinosa lucerne sown with perennial grasses for grazing, but there is little supporting evidence for this, either from Vartha (1973) or our own work. Our results show that sowings of pure lucerne will give highest dry matter yields, and that perennial grasses markedly suppress the yield of lucerne.

College Glutinosa was selected as a vigorous rhizomatous creeper and in this respect is much superior to the unimproved Glutinosa. The results of our measurements at Ashley Dene would suggest that the amount of creep is closely related to soil bulk density: where a soil is compacted little creep may occur. Similar results have been observed with creeping rooted lucernes in Australia (Rogers, 1967) and with a College Glutinosa selection at Lincoln (Vartha, 1973). However, we have obtained excellent rhizomatous creep in College Glutinosa lucerne when oversown on steep dry slopes at Hunua, North Canterbury, where the soil surface is loose and friable. The techniques of establishing lucerne on steep, dry, hill country are now quite well known (White, 1970a, b; Musgrave et al., 1974) and our results indicate that College Glutinosa may be a valuable cultivar for this purpose because of its creeping habit; high crown shoot production and consequent persistence. These features also give it greater ability to withstand mismanagement, an important consideration on hill country where regular spelling may not always be possible. 
In all the grazing trials College Glutinosa was inoculated with commercial strains of Rhizobium meliloti, which were observed to form effective nodules. This has been confirmed by Leach (1968) who found commercial strains SU47 and U45 to give a satisfactory level oh effectiveness on Glutinosa. White (1967) has postulated that some M. falcata ecotypes may tolerate more acid soils than M. sativa and thus have a reduced requirement for lime. The field trials of White (1970a), however, showed that College Glutinosa had a similar lime requirement to Wairau.

Creeping lucernes sometimes suffer the disadvantage of being poor seed producers (Heinrichs, 1963) but College Glutinosa was selected for seed production before release and several highyielding commercial crops have since been produced. Like Wairau, it is known to be susceptible to attack by stem nematode (Ditylenchus dipsaci) and bacterial wilt (Corynebacterium insidiosum) and therefore should not be used on soils which are wet for long periods or are irrigated.

\section{ACKNOWLEDGEMENTS}

The authors are grateful for the assistance of Professor R. H. M. Langer and R. F. B. Moir, Plant Science Department, Lincoln College, and R. C. Stephen, G. W. Nixon, W. Stiefel and A. Thompson, Ministry of Agriculture and Fisheries, in this programme of work.

\section{REFERENCES}

Calder, J. W.; Iversen, C. E., 1957: The new grazing types of lucerne. Canterbury Chamber of Commerce Bull. 334 .

Heinrichs, D. H., 1963: Creeping alfalfas. Adv. Agron., 15: 317-37.

Iversen, C. E., 1961: Ann. Rev. Canty Agric. Cdl.: 82-3.

1965: Lucerne: its potentiality and methods of achieving its potentiality. Proc. Lincoln Coll. Fmrs' Conf., 15: 78-83.

1967: Grazing management of lucerne. In The Lucerne Crop: 129-33 (Ed. R. H. M. Langer). Reed, Wellington.

Iversen, C. E.; Meijer, G., 1967: Types and varieties of lucerne. In The Lucerne Crop: 74-84 (Ed. R. H. M. Langer). Reed, Wellington.

Janson, C. G.; Knight, T. L., 1972: Lucerne variety trials. N.Z. Jl A gric., 124 (1): 21.

Leach, G. I., 1968: The effectiveness of nodulation of a wide range of lucerne cultivars. Aust. J. exp. A gric. Anim. Husb., 8: 323-6.

Musgrave, D. J., 1972: Shoot Development in Lucerne. M.Agr.Sc. thesis, Lincoln College. $148 \mathrm{pp}$.

Musgrave, D. J.; Clare, R. J.; Lowther, W. L., 1974: The potential for oversowing lucerne on steepland soils in North and Central Otago. Proc. N.Z. Grassld Ass., 36: 89-96. 


\section{COLLEGE GLUTINOSA LUCERNE}

Rogers, Veronica, E., 1967: Adaptability of luceme to soil and climate. In The Lucerne Crop: 36-46 (Ed. R. H. M. Langer). Reed, Wellington.

Vartha, E. W., 1973: Performance of luceme-grass pastures on Wakanui silt loam. N.Z. $/ l$ exp. Agric., 1: 29-34.

White, J. G. H., 1967: Establishment of lucerne on acid soils. In The Lucerne Crop: 105-13 (Ed. R. H. M. Langer). Reed, Wellington.

1970a: Establishment of lucerne (Medicago sativa L.) in uncultivated country by sodseeding and oversowing. Proc. 11th int. Grassld Congr.: 134-8.

1970b: Establishment of lucerne by sodseeding and oversowing in tussock country. Tussock Grasslds and Mountain Lands Inst. Rev., 20: 33-41. 